\title{
Antibacterial Susceptibility of the Constituents of Ethanol Crude Extract and the Neutral Metabolite of the Root of Curculigo pilosa Hypoxidaceae
}

\author{
D. C. Nwokonkwo ${ }^{1}$ \\ ${ }^{1}$ Faculty of Physical Sciences, Industrial Chemistry Department Ebonyi State, University Abakaliki, Nigeria \\ Correspondence: D. C. Nwokonkwo, Faculty of Physical Sciences, Industrial Chemistry Department Ebonyi \\ State, University Abakaliki, Nigeria. E-mail: mirinkwa@gmail.com
}

Received: August 29, 2014 Accepted: September 30, 2014 Online Published: October 20, 2014

doi:10.5539/ijc.v6n4p19

URL: http://dx.doi.org/10.5539/ijc.v6n4p19

\begin{abstract}
Powdered fresh rhizomes of Curculigo pilosa Hypoxidaceae (African Crocus) were analyzed for their phytochemicals and antibacterial activities. The crude ethanol extract showed the presence of saponins, flavonoids, steroids, alkaloids, glycosides and phenols. This crude sample was partitioned into acidic, basic and neutral metabolites. The neutral portion indicated the presence of saponin, flavonoid, steroid, glycoside, phenol and alkaloid. The antimicrobial susceptibility tests using the crude sample and the metabolites were carried out on four human pathogens; Escherichia coli, staphylococcus aureus, pseudomonas aeruginosa and streptococcus faecalis. At a concentration of $100 \mathrm{mg} / \mathrm{mL}$ : the crude sample showed IZD values of $22 \mathrm{~mm}$ for Escherichia coli, $29 \mathrm{~mm}$ for staphylococcus aureus, $23 \mathrm{~mm}$ for pseudomonas aeruginosa and $38 \mathrm{~mm}$ for streptococcus faecalis. The neutral metabolite at the same concentration gave IZD values of $35 \mathrm{~mm}$ for Escherichia coli, $36 \mathrm{~mm}$ for staphylococcus aureus, $35 \mathrm{~mm}$ for pseudomonas aeruginosa and $43 \mathrm{~mm}$ for streptococcus faecalis. The acidic and basic metabolites did not show any significant antibacterial activity. The control drug ampiclox at 100 $\mathrm{mg} / \mathrm{mL}$ showed IZD values of $40 \mathrm{~mm}$ for Escherichia coli; $32 \mathrm{~mm}$ for staphylococcus aureus; $26 \mathrm{~mm}$ for pseudomonas aeruginosa and $22 \mathrm{~mm}$ for streptococcus faecalis respectively. The minimum inhibitory concentration (MIC) of the ethanol crude extract and the neutral metabolite were at $25 \mathrm{mg} / \mathrm{mL}, 50 \mathrm{mg} / \mathrm{mL}$ and $100 \mathrm{mg} / \mathrm{mL}$, the result apparently justified the use of fresh rhizomes of Curculigo pilosa in the treatment of infections.
\end{abstract}

Keywords: antimicrobial, neutral, phytochemicals, root, tests

\section{Introduction}

Plants have been major sources of medicine and plant secondary metabolites have been attributed to most plant therapeutic activities (Fabeku, 2006; Neumann \& Hirsch, 2000). Phytochemicals have shown great promise in the treatment of intractable infectious diseases (Yesileda, 2005). The local uses of plants and plant products in health care are even much higher particularly in those areas with little or no access to modern health services (Saed, Arshad, M. Ahmad, E. Ahmad, \& Ishaque, 2004). Traditional medicine is a source of primary health care to $80 \%$ of the world's population (Alves \& Rosa, 2005; Pei, 2001) the use of herbal medicine has always been part of human culture, and African culture is one of them.

Several herbs from plants most especially have various pharmacologically active compounds that have the potential for the prevention/treatment of several cancers. The antioxidant potency of flavonoids in medicinal plants possess a variety of anticancer effects such as arrest of cell growth, inhibition of kinase activity, induction of apoptosis, reduction in tumour-invasive behavior and suppression of matrix metalloproteinase's secretion (Chau et al., 2000). Many African plants have been hypothesized to have phytochemicals that make them effective anti-inflammatory, antihypertensive, antitussive, antibiotics, anticancer agents and so on.

This article looked at one of these numerous Nigerian's medicinal plants, Curculigo pilosa. Curculigo pilosa Hypoxidaceae is known as "epakun" in Yoruba language; "orima" in Edo language, "dòòár kùréégéé" in Hausa language and "pkeve' in Tiv languge. The plant is used in herbal or traditional medicine to treat leukemia, gonorrhea, cough, as astringent agent, aphrodisiac and demulcent in Southwestern Nigeria (Odugbemi \& Akinsulire, 2006); there is a hypothesis that the rhizomes could possess anti-cancer or anti-tumour properties. 
Soladoye et al. (2012) reported its use as an antidiabetic; the vasoconstictive activity of its benzylbenzoate and non-lignan glucosides were also reported (Palazzino, Galeffi, Federici, Monache, Cometa, \& Palmery, 2000).

The research investigated the phytochemicals present in the crude ethanol extract of this plant species and the neutral metabolite derived from it. Also the antibacterial susceptibility of this crude sample and its neutral metabolite were verified. The root of Curculigo pilosa Hypoxidaceae from this work had shown itself as a highly promising source of potent antimicrobial drug. It is obviously worthy of large scale investment as the need for antimicrobial, antifungal and antiviral drugs against resistant pathogens persist around the globe.

\section{Experimental}

\subsection{Plant Material}

The fresh root of Curculigo pilosa $(350 \mathrm{~g}$ ) was purchased from Awolowo Market in Mushin local government of Lagos State in the month of June 2012 and identified by Applied Biology Department, Ebonyi State University Abakaliki. It was washed with distilled water to remove dirt, oven dried at moderate temperature for two days, pulverized and stored in sealed cellophane until needed. Test organisms candida albicans, streptococcus faecali, escherichia coli, pseudomonas aeruginosa, staphylococcus aureus and coliform bacilli were obtained from the Applied Microbiology Department of Ebonyi State University Abakaliki. All reagents used were of analytical grade.

\subsubsection{Extraction}

About $300 \mathrm{~g}$ of the ground sample was soaked in an aspirator bottle in $500 \mathrm{~mL}$ of ethanol and allowed to stay for $72 \mathrm{~h}$. The solvent was filtered and the filtrate distilled off to obtain $50 \mathrm{~g}$ greenish gummy substance.

\subsubsection{Phytochemical Screening}

Ejele and Alinor method (2010) was used in the preparation of the acidic, basic and neutral metabolites. The crude sample and the acidic, basic and neutral metabolites were subjected to phytochemical analysis using the AOAC (2005) method and other methods (Nwokonkwo, 2009) for the presence or absence of saponin, flavonoid, alkaloid, glycoside, tannin, polyphenol and steroid.

\subsubsection{Antibacterial Activity}

Test organisms used were candida albicans, streptococcus faecali, escherichia coli, pseudomonas aeruginosa, staphylococcus aureus and coliform bacilli. Agar well diffusion method was used. A cork borer of $1 \mathrm{~cm}$ was used to perforate the Mueller-Hinton agar in aseptic condition. The turbidity of the sample was prepared according to Mcfarland standard; a sterile swab stick was used and rotated inside the inoculums. The swab was streaked evenly over the surface of the medium before introduction of the plant extract (Agah et al., 2011). The determination of the minimum inhibitory concentration (MIC) was carried out on the plant extracts at concentrations of $100 \mathrm{mg} / \mathrm{mL}, 50 \mathrm{mg} / \mathrm{mL}, 25 \mathrm{mg} / \mathrm{mL}, 12.5 \mathrm{mg} / \mathrm{mL}$ and $6.25 \mathrm{mg} / \mathrm{mL}$ according to the method proposed by George and Roger (2002). These were prepared in agar nutrient and distributed into sterile tubes into sterile test tubes. One (1) $\mathrm{mL}$ of the extract was separately added to the agar plates for the bacteria and poured into petri dishes. The test organism was spotted on the surface of the solidified extract-agar mixture in increasing order of concentration. The plates were allowed to dry for $30 \mathrm{~min}$ and incubated at $37^{\circ} \mathrm{C}$ for $18 \mathrm{~h}$, after which the plates were examined for microbial growth. The lowest concentration of the extract which showed little or no visible growth of the microorganism was taken as the MIC of the extract (Roberts, Shore, Paviour, Holland, \& Morris, 2006).

\section{Results and Discussion}

The phytochemical screening of the crude sample of plant extract is shown on Table 1 . The table showed the presence of saponin, flavonoid, steroid, alkaloid and glycoside but absence of tannin (Ejele \& Nwokonkwo, 2013). The phytochemical screening of the acidic, basic and neutral metabolite is shown in Table 2. In Table 2, the acidic metabolite showed the presence of saponin, flavonoid, steroid, glycoside and phenol but the absence of alkaloid and tannin. The basic metabolite showed the absence of tannin, flavonoid and steroid but contained saponin, alkaloid, glycoside and phenol. The neutral metabolite showed the presence of all the phytochemicals except tannin. Inhibition zone diameter of the crude sample, acidic, basic and neutral metabolites is shown on Table 3 while Table 4 explains the inhibition zone diameter of the control drug. The crude sample showed IZD values of $22 \mathrm{~mm}, 29 \mathrm{~mm}, 23 \mathrm{~mm}$ and $38 \mathrm{~mm}$ at $100 \mathrm{mg} / \mathrm{mL}$ for Escherichia coli, Pseudomonas aeruginosa, Streptococcus faecalis and Staphylococcus aureus respectively. The IZD values obtained showed that the crude sample was potent against the organisms used in the analysis. The IZD values for the neutral metabolite at 100 $\mathrm{mg} / \mathrm{mL}$ were $35 \mathrm{~mm}, 36 \mathrm{~mm}, 35 \mathrm{~mm}$ and $43 \mathrm{~mm}$ for Escherichia coli, Pseudomonas aeruginosa, Streptococcus 
faecalis and Staphylococcus aureus, a positive result also indicating the potency of this plant species. The MIC of the crude and neutral metabolite on these microorganisms was at $25 \mathrm{mg} / \mathrm{mL}, 50 \mathrm{mg} / \mathrm{mL}$ and $100 \mathrm{mg} / \mathrm{mL}$. The IZD values of the neutral metabolite were significantly high compared to the control drug except in the case of Escherichia coli where the control drug at $100 \mathrm{mg} / \mathrm{mL}$ gave IZD value of $40 \mathrm{~mm}$. Alkaloids, phenols, glycosides and saponins have proven to have antibacterial, antifungal, astringent and such like properties and might be the reason why the crude extract gave positive result for the antimicrobial tests. The neutral metabolite which had the same constituents as the crude had higher IZD values and invariably higher inhibitory action against the pathogens. This probably indicated that these active principles were present in high concentration (s) in this medium. The concentration of the alkaloid, saponin and phenol in the basic medium might not have been significant enough to produce the required antibacterial activity. Also, the concentration of the saponin and phenol in the acidic medium might also not have been enough for the lethal dose required for it to be bacteriostatic or bactericidal. The extracts from these two media showed no appreciable MIC at $25 \mathrm{mg} / \mathrm{mL}, 50$ $\mathrm{mg} / \mathrm{mL}$ and $100 \mathrm{mg} / \mathrm{mL}$.

Table 1. Phytochemical screening of the ethanol crude extract of the plant sample

\begin{tabular}{|c|c|c|}
\hline Test & Observation & Inference \\
\hline Tannin: & formation of bluich precinitate & Tanins \\
\hline $2 \mathrm{~mL}$ sample $+5 \mathrm{~mL} \mathrm{H}_{2} \mathrm{O}+2$ drops $\mathrm{FeCl}_{3}$ & Iormation or biuisn precipitate & indicated \\
\hline Saponin: & formation of frothing & saponin \\
\hline $2 \mathrm{~mL}$ sample $+5 \mathrm{~mL} \mathrm{H}_{2} \mathrm{O}$ and $2 \mathrm{~mL}$ olive oil & formation of frothing & indicated \\
\hline Flavonoid: & formation of white nrecinitate & flavonoid \\
\hline $2 \mathrm{~mL} 10 \% \mathrm{NaOH}+2 \mathrm{~mL} 10 \% \mathrm{HCl}$ & Iormation or white precipitate & ndicated \\
\hline Steroid: & formation of dork hrown colour & steroid \\
\hline $\mathrm{CHCl}_{3}+5 \mathrm{~mL}$ conc. $\mathrm{H}_{2} \mathrm{SO}_{4}$ & IOMTatIon or dark-Drown colour & indicated \\
\hline Alkaloid: & formation of nrecinitate & alkaloid \\
\hline $2 \mathrm{~mL}$ Wagner's reagent $+2 \mathrm{~mL}$ sample & & indicated \\
\hline $\begin{array}{l}\text { Glycoside: } \\
0.5 \mathrm{~mL} \mathrm{CHCl}{ }_{3} \text { layer }+2 \mathrm{~mL} \mathrm{CH} \mathrm{CHOH}_{3} \mathrm{COO} \\
\mathrm{mL} \text { conc. } \mathrm{H}_{2} \mathrm{SO}_{4}\end{array}$ & $\begin{array}{l}\text { formation of two layers with reddish-brown } \\
\text { colour at interface }\end{array}$ & $\begin{array}{l}\text { glycoside } \\
\text { indicated }\end{array}$ \\
\hline $\begin{array}{l}\text { Phenol: } \\
0.5 \mathrm{~mL} \text { sample }+4 \mathrm{~mL} \mathrm{H}_{2} \mathrm{O}+0.3 \mathrm{~mL} 1.0 \mathrm{M} \\
\mathrm{FeCl}_{3} \text { solution }\end{array}$ & dark-brown precipitate formed & $\begin{array}{l}\text { phenol } \\
\text { indicated }\end{array}$ \\
\hline
\end{tabular}

Table 2. Phytochemical screening of the acidic, basic and neutral metabolites

\begin{tabular}{llll}
\hline Phytochemical & Acidic Metabolite & Basic Metabolite & Neutral Metabolite \\
\hline Tannin: & not indicated & not indicated & not indicated \\
Saponin: & not indicated & indicated & indicated \\
Flavonoid: & not indicated & not indicated & indicated \\
Steroid: & indicated & not indicated & indicated \\
Alkaloid: & not indicated & indicated & indicated \\
Glycoside: & indicated & indicated & indicated \\
Phenol: & indicated & indicated & indicated \\
\hline
\end{tabular}


Table 3. Inhibition zone diameter of the crude sample, acidic, basic and neutral metabolites

\begin{tabular}{lcccc}
\hline \multirow{2}{*}{ Test Organisms } & \multicolumn{4}{c}{$\begin{array}{c}\text { Diameter of Zone of Inhibition(mm) } \\
\text { Concentration (100 mg/mL) }\end{array}$} \\
\cline { 2 - 5 } & Crude & Acidic & Basic & Neutral \\
\hline Escherichia coli & 22 & - & - & 35 \\
Pseudomonas aeruginosa & 29 & - & - & 36 \\
Streptococcus faecalis & 23 & - & - & 35 \\
Staphylococcus aureus & 38 & - & - & 43 \\
\hline
\end{tabular}

Table 4. Inhibition Zone diameter of Ampliclox the control drug

\begin{tabular}{lc}
\hline \multirow{2}{*}{ Test Organisms } & $\begin{array}{c}\text { Diameter of Zone of Inhibition(mm) } \\
\text { Concentration (100 mg/mL) }\end{array}$ \\
\cline { 2 - 2 } & Ampiclox \\
\hline Escherichia coli & 40 \\
Pseudomonas aeruginosa & 32 \\
Streptococcus faecalis & 26 \\
Staphylococcus aureus & 22 \\
\hline
\end{tabular}

The partitioning of the crude sample into acidic, basic and neutral metabolites presented a new method of investigation as it helped in concentrating the active constituents/phytochemicals into acidic, basic and neutral media or as in this case, the neutral medium; and would make isolation through column chromatography and final characterization of the isolates easier.

Further research is still continuing; to isolate each phytochemical, test the susceptibility to microorganisms and structure elucidation.

\section{References}

Agah, M. V. et al. (2011). Antifungal activity of some selected plant extracts in Nigeria. Asian Journal of Microbiology, Biotechnology and Enviromental Science, 13(1), 87-89.

Alves, R. R., \& Rosa, I. L. (2005). Why study the user of plants in traditional medicines? Journal of Ethnomedicine, 1, 1-5. http://dx.doi.org/10.1076/phbi.39.7.74.5869

AOAC. (2005). Official Methods of Analysis (15th ed.). Washington D.C.: Association of Official Analytical Chemist.

Chau, B. N. et al. (2000). A Novel inhibitor of caspase activation binds bcl- $\mathrm{x}_{\mathrm{L}}$ and apaf-1. Molecular Cell Biology, 6, 31-40.

Ejele, A. E., \& Alinor, J. I. (2010). Anti-sickling potentials of aloe vera extract. effects of acidic, basic and neutral metabolites on the gelling and sickling of human hbss erythrocytes. International Journal of Natural and Applied Sciences, 6(2), 155-160.

Ejele, A. E., \& Nwokonkwo, D. C. (2013). Effect of microbial spoilage on an antimicrobial potential and phytochemical composition of ipecae root extract. International Research Journal of Microbiology, 4(4), 106-112.

Fabeku, P. O. (2006). Traditional medicine: The art, ways and practice. In T. Odugbemi (Ed.), outlines and pictures of medicinal plants from Nigeria (pp. 13-24). University of Lagos Press.

George, D. P., \& Roger, M. D. (2002). Encyclopaedia of Medicinal Plant (5th ed.). Spainish 1.

Neumann, R. R., \& Hirsch, E. (2000). Commercialization of non-timber forest products: Review and analysis for research. Indonesia, 176.

Nwokonkwo, D. C. (2009). Phytochemical constitution and antimicrobial activity of the stem bark of ficus 
asperifolia (sand paper) tree. Journal of Chemical Society of Nigeria, 34(2), 119-122.

Odugbemi, T., \& Akinsulire, O. (2006). Medicinal Plants by Species Names. In Outlines and Pictures of Medicinal Plants from Nigeria. Nigeria: University of Lagos Press.

Palazzino, G., Galeffi, C., Federici, E., Monache, F. D., Cometa, M. F., \& Palmery, M. (2000). Benzylbenzoate and norlignan glucosides from curculigo pilosa: structural analysis and invitro vascular activity. Phytochemistry, 55, 411-417. http://dx.doi.org/10.1016/S0031-9422(00)00256-9

Pei, S. J. (2001). Ethnobotanical approaches to traditional medicine: some experiences from Asia. Pharmaceutical Biology, 39, 74-79.

Roberts, S. A., Shore, K. P., Paviour, S. D., Holland, D., \& Morris, A. J. (2006). Antimicrobial susceptibility of anaerobic bacteria in New Zealand. Journal of Antimicrobial Chemotherapy, 57, 92-98. http://dx.doi.org/10.1093/jac/dk1052

Saed, M., Arshad, M., Ahmad, M., Ahmad, E., \& Ishaque, M. (2004). Ethnophytotherapies for the treatment of various by the local people of selected areas of NWFP (Pakistan). Journal of Biological Science, 7, 1104-1108. http://dx.doi.org/10.3923/pjbs.2004.1104.1108

Soladoye, M. O. et al. (2012). An avalanche of plant species for the traditional cure of diabetes mellitus in south western Nigeria. Journal of Natural Product Plant Resources, 2, 60-72.

Yesileda, E. (2005). Past and future contributions of traditional medicine in the healthcare system of the middle east. Journal of Ethnopharmacolology, 100, 135-137. http://dx.doi.org/10.1016/j.jep.2005.06.003

\section{Copyrights}

Copyright for this article is retained by the author(s), with first publication rights granted to the journal.

This is an open-access article distributed under the terms and conditions of the Creative Commons Attribution license (http://creativecommons.org/licenses/by/3.0/). 